\title{
Secteur 3 : nord et sud de Nancy et de Toul jusqu'au nord des Vosges
}

\section{Michel Loiseau}

\section{(2) OpenEdition Journals}

Édition électronique

URL : http://journals.openedition.org/adlfi/9119

ISSN : 2114-0502

Éditeur

Ministère de la culture

Référence électronique

Michel Loiseau, "Secteur 3 : nord et sud de Nancy et de Toul jusqu'au nord des Vosges », ADLFI.

Archéologie de la France - Informations [En ligne], Lorraine, mis en ligne le 01 mars 2001, consulté le 01 mai 2019. URL : http://journals.openedition.org/adlfi/9119

Ce document a été généré automatiquement le 1 mai 2019.

(c) Ministère de la Culture et de la Communication, CNRS 


\title{
Secteur 3 : nord et sud de Nancy et de Toul jusqu'au nord des Vosges
}

\author{
Michel Loiseau
}

Identifiant de l'opération archéologique : F1354200100069

Date de l'opération : 2001 (PA)

1 Vitrey, Les Rousselots

2 Traces d'un chemin fossile dans un parcellaire remembré.

3 Saulxures-lès-Vannes, Mérigny

4 Château de Mérigny, propriété de la famille Balivy au XVIII ${ }^{\mathrm{e}}$ s., peu après la révolution, fut détruit. Bâti à l'écart du village, dans la petite vallée de Taprey, il occupait un espace carré entouré de fossés.

5 LOISEAU Michel

\section{INDEX}

Index géographique : Lorraine

Thèmes : château, parcellaire

Index chronologique : Révolution française

operation Prospection aérienne (PA) 